\title{
An adult cystidicolid nematode (Nematoda: Cystidicolidae) from the subcutaneous tissue around the eye of percupinefish, Diodon nichthemerus Cuvier
}

\author{
${ }^{1}$ School of Veterinary Medicine, Rakuno Gakuen University, Hokkaido, Japan; \\ ${ }^{2}$ Osaka Aquarium Kaiyukan, Osaka, Japan; \\ ${ }^{3}$ Nifrel, Osaka, Japan
}

Kozue Sasaki $^{1}$, Yoshimi Miyagawa ${ }^{2}$, Itsuki Kiyatake ${ }^{2}$, Kiyoko Onda ${ }^{3}$, Takaomi Ito ${ }^{2}$ and Mitsuhiko Asakawa

\begin{abstract}
Three adult nematode specimens, all ovigerous females belonging to the family Cystidicolidae Skryabin, 1946, were found for the first time in the subcutaneous tissue around the eye of the captive porcupinefish Diodon nichthemerus Cuvier at a public aquarium in Osaka, Japan. Because no male was available, these could not be identified to the genus and species. This case highlights the risk of parasitism in aquaculture puffer fish, as these may ingest small shrimp, which probably act as intermediate hosts for the nematode.
\end{abstract}

Keywords: Habronematoidea, parasite, marine fish, Diodontidae, Japan

In May 2015, a porcupinefish, Diodon nichthemerus Cuvier (Tetraodontiformes: Diodontidae), that had been imported from South Australia and raised at Osaka Aquarium Kaiyukan in Osaka, Japan, was found to harbour a parasitic lesion in the upper part of the subcutaneous tissue surrounding the left eye of $D$. nichthemerus (Fig. 1A). After anesthetising the fish by 2-phenoxyethanol, three nematodes were surgically extracted from the lesion; they were milky in colour, flexible, slender and string-shaped (Fig. 1B). These were then fixed in $70 \%$ ethanol and stained with lactophenol solution. Drawings were made with the aid of a microscope (Olympus BH2-DH) drawing attachment.

The nematodes were $80-109 \mathrm{~mm}$ long, with a slightly rounded cephalic end (Figs. 2A, 3B). There were four papillae around the oral opening (Figs. 2B, 3C). The uterus and vulva were observed in these nematodes (Figs. 2C, $3 \mathrm{D})$, so they were identified as female. The uteri contained non-larvated oval eggs, size 60-67 $\mu \mathrm{m} \times 30-40 \mu \mathrm{m}$; each egg had long filaments, over $500 \mu \mathrm{m}$ long (Figs. 2D, 3E), at each pole. The tail end was blunt and assumed a conical shape (Figs. 2E, 3F).

The structure of the cephalic end shows clearly that this parasite belongs to the Cystidicolidae (see Chabaud 1975, Moravec 2007), but its closer identification was not possible mainly because of the absence of the male. Therefore, for the time being, we designate these nematodes as Cystidicolidae gen. sp.

In the recent study of Soto et al. (2013), adult cystidicolid nematodes were found to cause exophthalmia in the

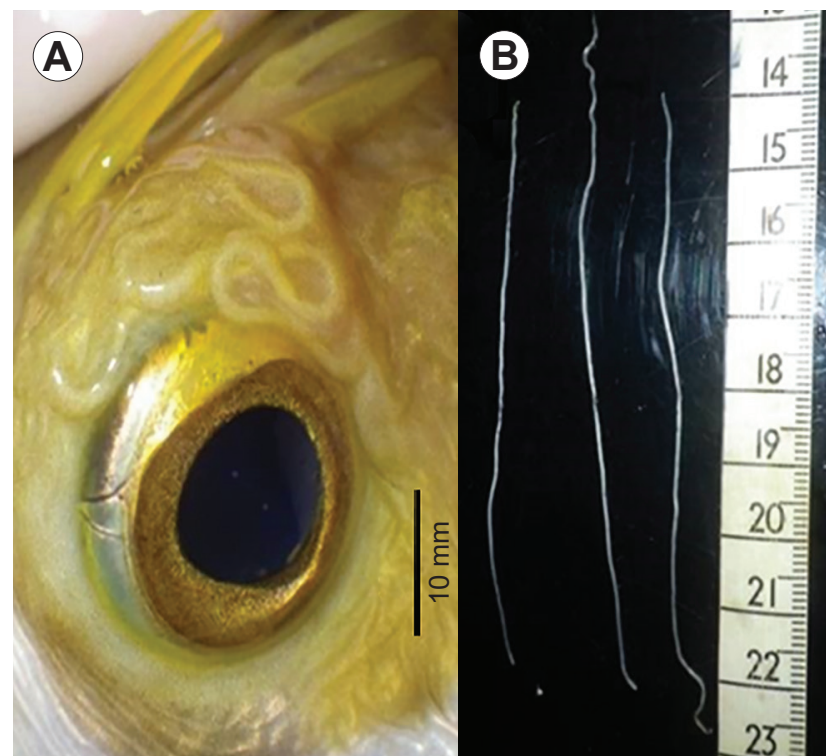

Fig. 1. A - parasitic lesion of Cystidicolidae in the subcutaneous tissue of Diodon nichthemerus Cuvier; B - parasitic nematodes extracted from the lesion.

Caribbean porcupinefish, Diodon hystrix Linnaeus. These were reported as Metabronema sp., but the generic identification was based solely on available histological sections and is, therefore, questionable. In contrast to species of $\mathrm{Me}$ tabronema Yorke et Maplestone, 1926 (see Moravec and Justine 2007), the present specimens from D. nichthemerus have a very different shape and structure of pseudolabia and 

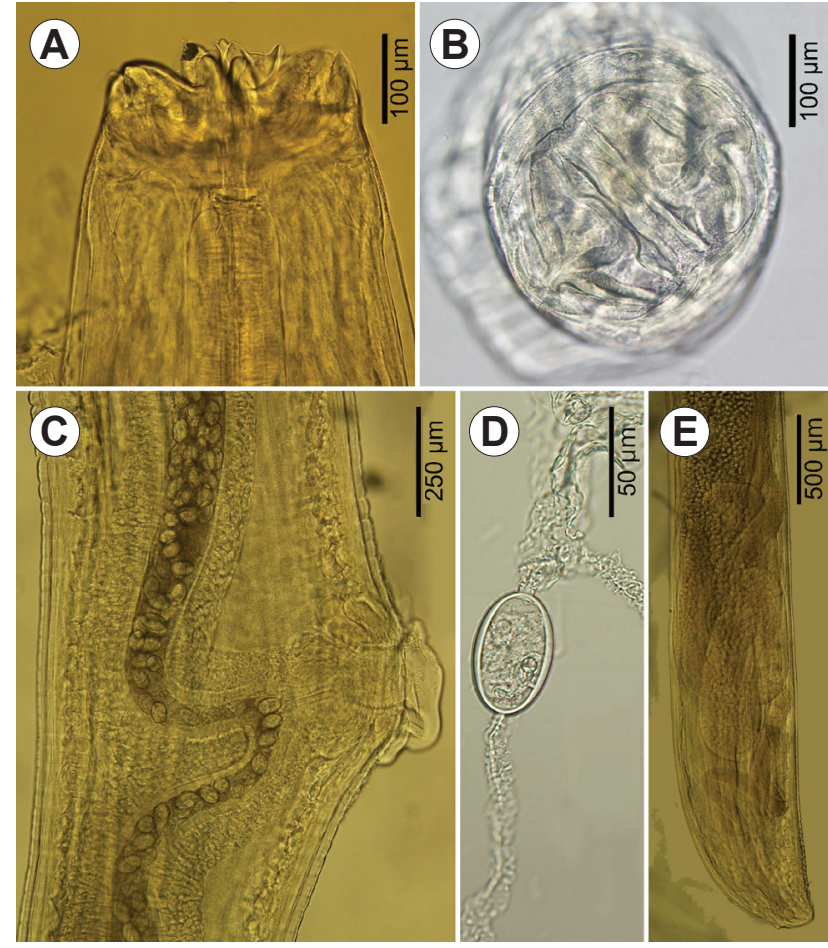

Fig. 2. Cystidicolidae gen. sp. from Diodon nichthemerus Cuvier. $\mathbf{A}$ - anterior extremity, lateral view; $\mathbf{B}$ - cephalic end, apical view; $\mathbf{C}$ - vulva, lateral view; $\mathbf{D}$ - egg; $\mathbf{E}$ - tail end, lateral view.

a very short vestibule. Taking into account the unusual localisation of these parasites in the host, they probably belong to a new, so far undescribed genus and species. Anyway, this is the first report of mature cystidicolid nematodes localised in the subcutaneous tissue around the eye of marine fish.

Cystidicolids are mostly transmitted through eating small shrimp, which usually act as intermediate hosts (Martorelli et al. 2000). If the present nematode has a similar infection route, there is a risk that it may parasitise farmed or pet puffer fish (Tetraodontiformes), which are closely related to the present fish host species both phylogenetically and ecologically (Leis 1978).

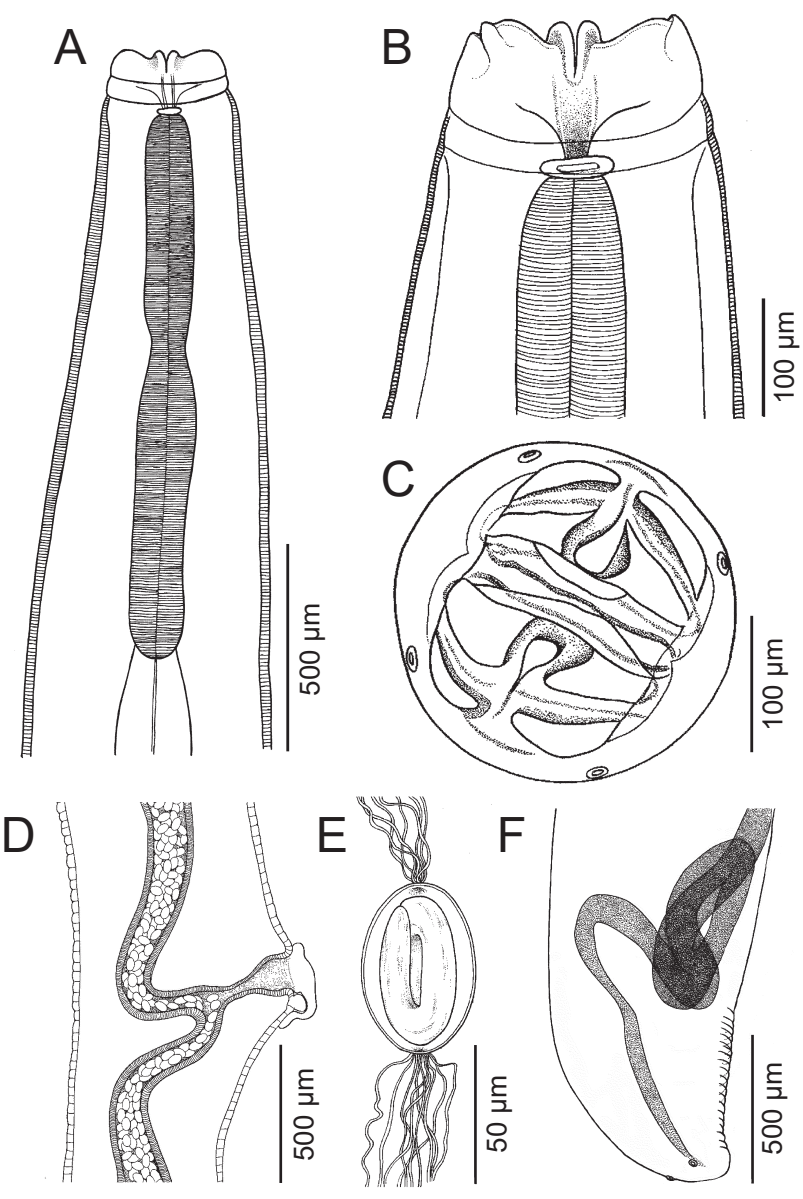

Fig. 3. Cystidicolidae gen. sp. from Diodon nichthemerus Cuvier. $\mathbf{A}$ - anterior extremity, lateral view; B, C - cephalic end, lateral and apical views, respectively; D - vulva, lateral view; $\mathbf{E}$ - egg, $\mathbf{F}$ - tail end, lateral view.

This study was partly supported by a Grant-in-Aid for Scientific Research (C-23570120, C-26460513) from the Ministry of Education, Culture, Sports, Science and Technology of Japan

\section{REFERENCES}

Chabaud A.G. 1975: Keys to genera of the order Spirurida. Part 2. Spiruroidea, Habronematoidea and Acuarioidea. In: R.C. Anderson, A.G. Chabaud and S. Willmott (Eds.), CIH Keys to the Nematode Parasites of Vertebrates. No. 3. Conmonwealth Agricultural Bureaux, Wallingford, pp. 28-58.

LEIS J.M. 1978: Systematics and zoogeography of the porcupine fishes (Diodon, Diodontidae, Tetraodontiformes) with comments on egg and larval development. NOAA Fish. Bull. 76: 535-567.

Martorelli S.R., Navone G.T., Ivanov V. 2000: Proposed life cycle of Ascarophis marina (Nematoda: Cystidicolidae) in Argentine waters. J. Parasitol. 86: 1047-1050.
Moravec F. 2007: Some aspects of the taxonomy and biology of adult spirurine nematodes parasitic in fishes: a review. Folia Parasitol. 54: 239-257.

Moravec F., Justine J.-L. 2007: Redescription of Metabronema magnum (Nematoda: Cystidicolidae), a swimbladder parasite of the carangid fish Gnathanodon speciosus off New Caledonia. Folia Parasitol. 54: 293-300.

Soto E., Bogdanovic L., Krecek R.C., Javonovich J.A., Arauz M., Overstreet R.M. 2013: Parasitosis of Metabrone$m a$ sp. (Nematoda: Cystidicolidae) in Caribbean porcupinefish, Diodon hystrix (L.). J. Fish Dis. 36: 1031-1034.

Cite this article as: Sasaki K., Miyagawa Y., Kiyatake I., Onda K., Ito T., Asakawa M. 2017: An adult cystidicolid nematode (Nematoda: Cystidicolidae) from the subcutaneous tissue around the eye of percupinefish, Diodon nichthemerus Cuvier. Folia Parasitol. 64: 021. 